\title{
Erratum: Late Ordovician-early Silurian destruction of the Iapetus Ocean: Newfoundland, British Isles and Scandinavia-a discussion
}

[Transactions of the Royal Society of Edinburgh: Earth Sciences 79 (1988), 361-382]

Kevin T. Pickering, Michael G. Bassett and David J. Siveter

In this paper, on page 375, we published an Arenig palaeogeography in Figure 6 which showed the subduction zone off Laurentia as dipping northwards. This was a drafting error. The subduction zone should have dipped southward away from Laurentia. We apologise for this error and publish here a revised Figure 6 for the Arenig.

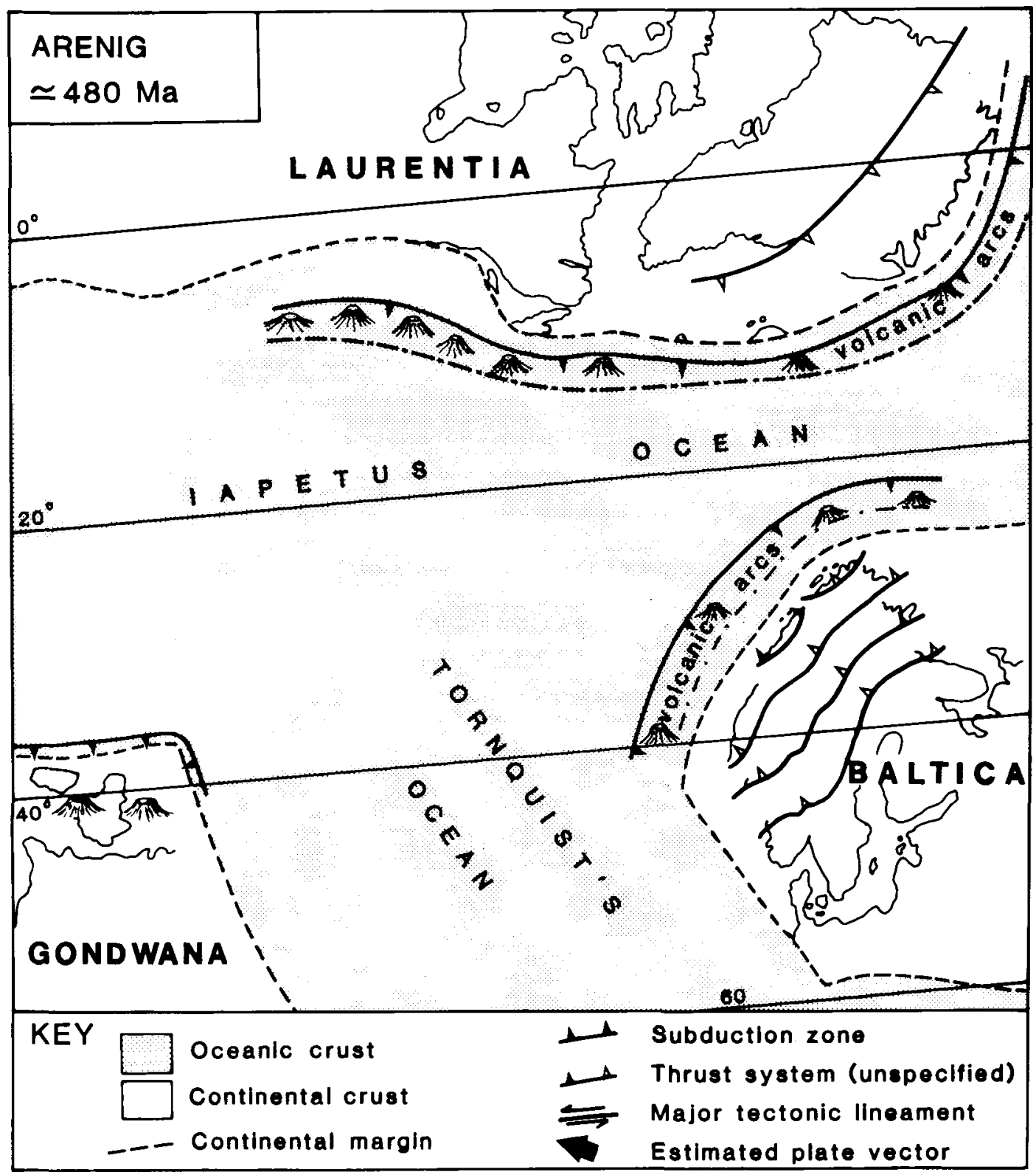

KEVIN T. PICKERING and DAVID J. SIVETER, Department of Geology, University of Leicester, Leicester LE1 7RH, U.K. MICHAEL G. BASSETT, Department of Geology, National Museum of Wales, Cathays Park, Cardiff CF1 3NP, Wales, U.K. 